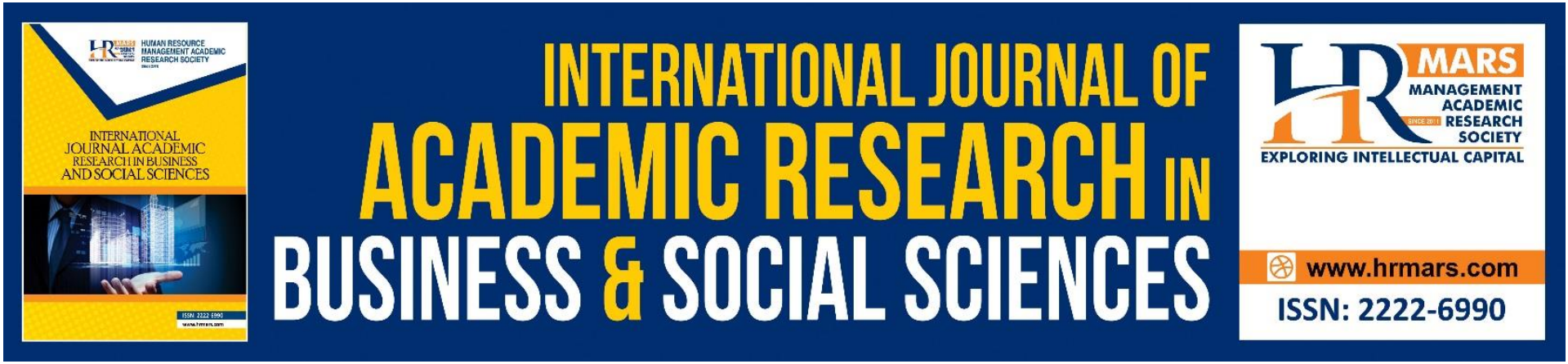

\title{
Prioritizing Internal Marketing in Islamic Services Organization
}

\section{Murni Yusoff}

To Link this Article: http://dx.doi.org/10.6007/IJARBSS/v11-i11/11553

DOI:10.6007/IJARBSS/v11-i11/11553

Received: 06 September 2021, Revised: 30 September 2021, Accepted: 18 October 2021

Published Online: 02 November 2021

In-Text Citation: (Yusoff, 2021)

To Cite this Article: Yusoff, M. (2021). Prioritizing Internal Marketing in Islamic Services Organization. International Journal of Academic Research in Business and Social Sciences, 11(11), 542 - 549.

Copyright: (c) 2021 The Author(s)

Published by Human Resource Management Academic Research Society (www.hrmars.com)

This article is published under the Creative Commons Attribution (CC BY 4.0) license. Anyone may reproduce, distribute, translate and create derivative works of this article (for both commercial and non-commercial purposes), subject to full attribution to the original publication and authors. The full terms of this license may be seen at: http://creativecommons.org/licences/by/4.0/legalcode

Vol. 11, No. 11, 2021, Pg. $542-549$

Full Terms \& Conditions of access and use can be found at http://hrmars.com/index.php/pages/detail/publication-ethics 


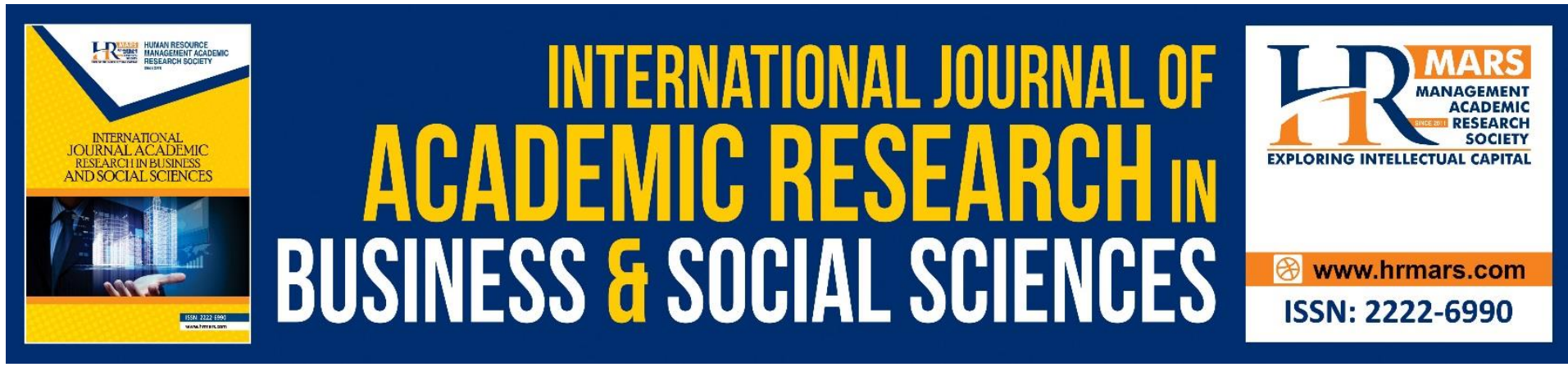

\title{
Prioritizing Internal Marketing in Islamic Services Organization
}

\author{
Murni Yusoff \\ Centre for Islamic Development Management Studies (ISDEV), Universiti Sains Malaysia, \\ 11800 USM, Penang.
}

\begin{abstract}
Internal marketing has been emphasized by marketing scholars as it brings success in achieving the goals and sustainability of organizations. However, internal marketing seems to be ignored in certain ways in services organizations. The ignorance of the internal marketing practices leads to many internal problems and affect performance of the overall organization. This paper attempts to investigate the reasons to prioritize internal marketing in services organizations, particularly Islamic service organization. The instrument used to collect data is document research and analyzed using qualitative data analysis. The findings show that internal marketing could promote the organization's mission, vision, objectives, culture, services, and brand to its own employees, by treating the employee as important as the external customer. Employee will become the organization ambassador by practicing three Islamic values such as Ibadah, Ihsan, and Amanah to promote the services provided to the customer.
\end{abstract}

Keywords: Internal Marketing, Service Organizations, Islamic Service Organization

\section{Introduction}

In general, marketing actions involve internal and external marketing. Internal marketing is the key to superior service and the result is external marketing success (Greene et al., 1994). Internal marketing is defined by Rafiq \& Ahmed (2000) as:

A planned effort using a marketing-like approach to overcome organizational resistance to change and to align, motivate and infer functionally coordinate and integrate employees towards the effective implementation of corporate and functional strategies in order to deliver customer satisfaction through a process of creating motivated and customer orientated employees.

Meanwhile, external marketing is defined by Business Matters (2020) as:

External marketing is the action of promoting your business and its services. It's about getting people through the door and reaching as many people as possible who may be interested in employing your services. This type of marketing is most commonly undertaken with TV \& radio ads, flyers \& brochures, social media and search engine advertising. 
Internal marketing has two main ideas that highlight the vital role played by service employees. Firstly, the notion that every individual in a service organisation should recognise that they have customers to serve (both inside and outside the organisation). Secondly, in order to achieve this, all internal customers (employees) must be convinced about the quality of the service being provided, and be happy in their work (Doukakis \& Kitchen, 2004).

The ignorance of the internal marketing practices leads to internal problems and affect performance of the overall organizations as wells as the entire service industry. Internal marketing could be a serious matter to the service organization when internal problems exist has yet to be resolved. The internal problems in an organization act as a stumbling block for internal marketing to be successful (Paul \& Sahadev, 2018). Internal factors like leadership, organizational structure, communication, learning opportunities (for improving knowledge and skills) can lead to internal problems in the organization (Gleeson, 2019). Among the problems that occurred in organizations are high-level of staff absenteeism, employee turnover, lack of motivation and inadequate service quality, and unstable work atmosphere (Paul \& Sahadev, 2018).

This study aims to investigate the reasons to prioritize internal marketing in services organizations, particularly Islamic service organization. Islamic service organizations in this context of study refers to the organizations that provides Islamic services to customers/ clients without producing any tangible product. For instant, any services provided that comply with Shariah such as Islamic banking, Takaful, Fara'id, Zakat, Waqf, education and others. The method used to collect data is by using document research. Data is analyzed using qualitative data analysis.

This paper is organized into four parts. The first part brief on introduction. The second part presents literature review comprises of internal marketing and effect of internal marketing in service industry. The third part is the discussion on prioritizing internal marketing in Islamic service organization while the last part will conclude the overall discussion.

\section{Internal Marketing}

Many marketing scholars have emphasized on internal marketing as part of the marketing strategy in organizations. Internal marketing as is evolved in three stages such as employee motivation and satisfaction, customer orientation, and strategy implementation since the year 1976 (Rafiq \& Ahmed, 2000).

Berry (2002) has connected internal marketing as and external marketing in an organizational climate involve creating an organizational climate in general, and job-products in particular, that lead to the right service personnel performing the service in the right way. EM and IM have similar roles in the way of selling and reselling job in the context of IM while selling and reselling products including good and services in the context of EM.

Greene et al (1994) stated that internal marketing is implemented by applying the philosophy and practices of marketing to the people who serve the external customer so that the best possible people can be employed and retained and they will do the best possible work.

\section{Effect of Internal Marketing in Service Organization}

Number of studies have shown the effect of internal marketing in service organizations. Mishra (2010) has highlighted that internal marketing is a mechanism to ensure motivation 
of the employees in services industry in India and it also act as a tool in harnessing the power of employee by becoming client and customer in creating responsibility among them.

Besides, a study by Ahmad, Iqbal, and Sheeraz (2012) have found that internal marketing comprises of internal communication, training and motivation have positive effects on the employee retention. The result suggested that if the banks of Pakistan want to retain their employees for longer period of time, it is recommended that sufficient attention should be given to internal marketing.

Doukakis \& Kitchen (2004) found in their empirical study that UK retail banks have not taken internal marketing seriously save as a managerial tool. They have suggested the banks and other service organisations to adequately undertake an in-depth study of internal marketing and its application.

Herrington et al (2005) have studied the link between internal relationship building and external relationship building in the medical services industry, found that there is a moderate strong link between both relationships that represents the employee's perception of their relationship with their employer and their subsequent perceived ability to develop a relationship with customers. Those internal relationship exists from communication, attachment, shared goals, values, respect, cooperation, balanced power, trust, and absence of damaging conflict.

Further, Unal \& Ayse (2019) have studied effect of internal marketing on internal branding in banks of Turkey found that internal marketing practices have positive effects on the internal branding and therefore the enterprises' branding process. As the results, the managers should start from the employees first in the branding process and apply the internal marketing tools in their businesses accordingly. Managers should motivate the employees by contributing to their development with internal marketing and rewarding the employees. Managers should train their employees about the brand and keep them fit with group meetings while motivating them by contributing to their development and rewarding their employees through internal marketing.

Kunsman (2020) have shared the results conducted from other research on internal marketing such as Nielsen study showed that $84 \%$ of people trust recommendations from friends, family, colleagues over other forms of marketing; brand messages reached $561 \%$ further when shared by employees vs the same messages shared via official brand social channels (by MSLGroup); and content shared by employees receives $8 x$ more engagement than content shared by brand channels (by Social Media Today).

Ratnasari (2021) have studied internal marketing in Islamic banks emphasized that the higher employees performance at Islamic Banks in East Java is derived from the better the application of Islamic values in internal marketing such as motivation, innovation, resources, responsibility, communication, and spiritual work climate.

In a nutshell, most of the research found that internal marketing affect the employee through motivation, communication, resources, branding, and working climate towards their 
performance that may affect directly on the achievement of organizations goals and sustainability of the organizations.

\section{Prioritizing Internal Marketing in Islamic Service Organizations}

Islamic service organizations are unique in its mission and vision. As the Islamic service organizations provides Islamic services as main business, it is important to understand that the organization also need to market their services provided. Despite the fact that Islamic service organization is different from its counterpart, both marketing actions of internal and external also need to be applied in the organization.

From the previous part discussed, it clearly shown that there are impact of internal marketing on the performance of the overall organization. In other words, internal marketing is crucial matter to be considered and implemented successfully in the Islamic service organization.

There are five efforts of internal marketing that can be implemented in the organization as addressed by (Kunsman, 2020). Those efforts are educating employees on the company goals and values; encouraging employee input on corporate policies and leadership, allowing open dialogue and accepting any criticisms; nurturing communication and collaboration among employees; ensuring employees know that their contributions matter and are essential to the success of the company; and opening up the product or services to employees to use and get involved in.

In addition, Greene et al (1994) have identified another four efforts that can be implemented in the organization. Those efforts are by focusing on the most promising segments in service; creating reward system to the employees; providing marketing support programs such as training, collateral materials, and information system; and providing good coordination among all parties involved in the organization, including CEOs, managers, marketing personnel, branches, and the frontline selling personnel.

In prioritizing internal marketing to be prioritized in Islamic service organization, there are two types of relationships involved, namely relationship between man and Allah and relationship among man are applicable in marketing services. Both of these relationships are the foundation to be implemented in the Islamic service organizations.

The essence of internal marketing is to preserve the relationship between employer and employee. Hence, internal marketing need to prioritized in Islamic service organization to promote the organization's mission, vision, objectives, culture, services, and brand to its own employees, by treating the employee as important as the external customer. By doing that, the employee will become the organization ambassador.

This purpose is aligned with three Islamic values in working in the organization namely, Ibadah, Ihsan, and Amanah. First, working is considered Ibadah in Islam. One of the Quranic verses relate to Ibadah as follows:

And say, "Do [as you will], for Allah will see your deeds, and [so will] His Messenger and the believers. And you will be returned to the Knower of the unseen and the witnessed, and He will inform you of what you used to do." 
There is also Hadith related to working as Ibadah. One of the Hadith narrated by al-Baihaqi in Syu'ab al-Iman (9890) and al-Tabarani in Musnad al-Syamiyyin (3465) stated by Mohamad alBakri (2019) as follows:

Whoever seeks halal sustenance to keep himself from begging, and in order to provide for the family, as well as to be able to help his neighbors, he will surely come on the Day of Judgment with his face radiant like the moon on a full moon night.

From the above Quran and Hadith verse, it shows that the relationship between the man and Allah need to be preserved. As an employer or employee in the organization, he/she works to seek for Rizq for the sake of Allah as long as the he/she is doing the Halal works.

Second, practice Ihsan in working. According to Mohamed et al (2013), Ihsan means to perform a job with the best method (proficiency). The nature of Ihsan is closely related to the aspect of excellence in the job performed. Kadhim et al (2017) also highlighted the attributes of al-Ihsan that have positive effects on the morality of the individual Muslim and the development of his personality. They also have positive effects on an individual's social interaction. Five effects have been addressed such as kindness to both parents, kindness to the orphans and the needy, kindness to neighbors, and kindness to the unkind.

One of the Quranic verses related to Ihsan as follows:

On those who believe and do deeds of righteousness there is no blame for what they ate (in the past), when they guard themselves from evil, and believe, and do deeds of righteousness,- (or) again, guard themselves from evil and believe,- (or) again, guard themselves from evil and do good. For Allah loveth those who do good.

(Al-Maidah, 3: 93)

Third, Amanah (trustworthy) in working. One of the Quranic verses on Amanah:

Indeed, Allah commands you to render trusts to whom they are due and when you judge between people to judge with justice. Excellent is that which Allah instructs you. Indeed, Allah is ever Hearing and Seeing.

(An-Nisaa, 4: 58)

With Amanah embedded in all employer and employer in the organization, they will give the best the full commitment in doing their job. Kasim et al (2020) stated that the real Amanah is the belief among all of the beliefs and the complex social relationships that contribute to the mutual trust among community members. Amanah could provide a good impact on the individual righteousness and Integrity; sincerity in performing duties and responsibilities; approaching happiness and success through Amanah practice in this worldly life and the hereafter.

\section{Conclusion}

Internal marketing have shown many benefits and its importance to the organization. Prioritizing internal marketing in Islamic service organization could promote the achievement 
of organizations goals and sustainability of the organizations in long term. By incorporating the Islamic values such as Ibadah, Ihsan, and Amanah in employer employee personality, internal marketing performed by the organization can be successful way to engage the employee in the organization to become truly organization ambassador in promoting the services to the customer.

\section{Corresponding Author}

Murni Yusoff

Centre for Islamic Development Management Studies (ISDEV), Universiti Sains Malaysia, 11800 USM, Penang.

Email: murniyusoff@usm.my

\section{References}

Ahmad, N., Iqbal, N., \& Sheeraz, M. (2012). The effect of internal marketing on employee retention in Pakistani banks. International Journal of Academic Research in Business and Social Sciences, 2(8), 270- 280.

Berry, L. L. (2002). Relationship Marketing of Services- Perspectives from 1983 and 2000. Journal of Relationship Marketing, 1(1), 59-77.

Business Matters. (2020). What's the difference between internal and external marketing. https://bmmagazine.co.uk/marketing/whats-the-difference-between-internal-andexternal-marketing/.

Gleeson, P. (2019). Internal \& external factors affect organization. https://smallbusiness.chron.com/internal-external-factors-affect-organization16641.html.

Greene, W. E., Walls, G. D., \& Schrest, L. J. (1994). "Internal Marketing: The Key to External Marketing Success", Journal of Services Marketing, 8(4), 5-13.

Herington, C., Scott, D., Johnson, L. W. (2005). Focus Group of Firm-Employee Relationship Strength. Qualitative Market Research: An International Journal, 8(3), 256-276.

Kadhim, A. S., Ahmad, S., Owoyemi, M. Y., \& Ahmad, M. (2017). Islamic Ethics: The Attributes of Al-Ihsan in the Quran and Its Effects on Muslim Morality. International Journal of Business and Social Science, 8(11), 102-107.

Kasim, A. C., Dien, M. I., Kasim, S. C., \& Manap, J. (2020). The Impact of Amanah on Individual Manners and The Society. International Journal of Academic Research in Business and Social Sciences. 10(9), 629-640.

Kunsman, T. (2020). Internal Marketing: Why Your Company Should Prioritize It? https://everyonesocial.com/blog/internal-marketing/.

Mishra, S. (2010). Internal Marketing- A Tool to Harness Employee's Power in Service Organizations in India. International Journal of Business and Management, 5(1), 185 193.

Mohamed, H. A., Ghani, A. M. A., \& Basir, S. A. (2013). Islamic Management System Assures Employee's Satisfaction: Reality and Future Challenges. GJAT, 3(1), 67-84.

Said, N. A., \& Khairuldin. (2017). Freedom of Speech in Islam and its Connection with Street Demonstrations. International Journal of Academic Research in Business and Social Sciences, 7(4), 122-129.

Khairuldin, Embong, A. H., Anas, W. N. I. W. N., Ismail, D., Ibrahim, I., \& Fauzi, N. (2017). Freedom of Speech: A Comparative Study between Islam and Malaysian Laws. 
International Journal of Academic Research in Business and Social Sciences, 7(2), 2222-6990.

Ibrahim, I., \& Khairuldin. (2017). Fatwa as a Medium Da'wah: Studies on the Role of Mufti as a Preacher. International Journal of Academic Research in Business and Social Sciences, 7(4), 10-18.

Doukakis, I. P., \& Kitchen, P. J. (2004). Internal Marketing in UK Banks: Conceptual Legitimacy or Window Dressing? The International Journal of Bank Marketing, 22(6), 421-452.

Paul, J., \& Sahadev, S. (2018). Service Failure and Problems: Internal Marketing Solutions for Facing the Future. Journal of Retailing and Consumer Services, 40, 304-311.

Quran.com. https://quran.com.

Rafiq, M., \& Ahmed, P. K. (2000). Advances in the Internal Marketing Concept: Definition, Synthesis and Extension. Journal of Services Marketing, 14(6), 449-462.

Ratnasari, R. T. (2021). Islamic Leadership and Internal Marketing: Evidence from Islamic Banking. Review of International Geographical Education (RIGEO), 11(4), 407-417.

Unal, E., \& Ayse, A. (2019). The Effect of Internal Marketing on Internal Branding: An Empirical Research on Participation Banks in Turkey. Pazarlama ve Pazarlama Araştırmaları Dergisi, Sayı, 23, 95-121.

Al-Bakri, M. Z. (2019). Bekerja Sebagai Ibadah: Meningkatkan Integriti. https://muftiwp.gov.my/en/artikel/bayan-linnas/3555-bayan-linnas-siri-ke-193bekerja-sebagai-ibadah-meningkatkan-integriti. 